\title{
"To Preserve This Remnant:" William Apess, the Mashpee Indians, and the Politics of Nullification
}

Neil Meyer

\section{(2) OpenEdition}

\section{Journals}

Electronic version

URL: https://journals.openedition.org/ejas/12635

DOI: 10.4000/ejas. 12635

ISSN: 1991-9336

Publisher

European Association for American Studies

\section{Electronic reference}

Neil Meyer, "'To Preserve This Remnant:" William Apess, the Mashpee Indians, and the Politics of Nullification", European journal of American studies [Online], 13-2 | 2018, Online since 28 June 2018 , connection on 08 July 2021. URL: http://journals.openedition.org/ejas/12635 ; DOI: https://doi.org/ 10.4000/ejas. 12635

This text was automatically generated on 8 July 2021.

Creative Commons License 


\title{
"To Preserve This Remnant:" William Apess, the Mashpee Indians, and the Politics of Nullification
}

\author{
Neil Meyer
}

1 In the 1830s, while the state of Georgia fought a protracted battle in the Supreme Court to remove Cherokee Indians from gold-rich land in the state, a more local battle was taking place in the Cape Cod region of Massachusetts. The Indian community of Mashpee, made up of Wampanoag and other Indian nations, attempted to live a free existence as Christian Indians (Campisi 67). Local whites sought to take unfair and illegal advantage of their land and the state attempted to exert further control over them in matters both political and religious. The Mashpee fought back in person and in print and were joined by Pequot Indian and Methodist itinerant minister William Apess, who was adopted by the community and helped lead charges against the state's restrictive laws, their Harvard-appointed minister, and a local community that often took advantage of Mashpee resources.

2 Compared to the much-discussed removal policies imposed on the Cherokees contemporaneously, the "rebellion" at Mashpee appears smaller in scale and less widely known. But in this conflict with the Massachusetts government, the Mashpee community engaged provocatively in the discourses of states' rights and slavery that animated national conversations in the era of Cherokee removal and the South Carolina nullification crisis. And this battle produced the work, The Indian Nullification of the Unconstitutional Laws of Massachusetts, Relative to the Marshpee Tribe: or, The Pretended Riot Explained (1835), a documentary history of the Mashpee's political struggles, written collaboratively by Apess and the larger community. Indian Nullification enacts a singular political critique for its era, using the national conflict over slavery and states' rights to produce a specific discourse of resistance on behalf of their community's autonomy.

The national context for American Indian nations and their relationship to the U.S. government came out of two cases, Cherokee Nation v. Georgia (1831) and Worcester v. Georgia the following year; these cases revised the prior fifty years of the U.S.'s 
relationship to American Indian nations and shaped the public discourse around American Indians and land rights. But the title of the book makes direct reference to the "nullification crisis" brought about by the slave-holding elites of South Carolina. They claimed an extreme states' rights position around federal tariffs, which many understood to be a conflict around the federal government's ability to ultimately regulate slavery. By reading Indian Nullification through the discourses around Indian nations, states' rights, and slavery, we can see how Apess and the Mashpee saw the issues of the Cherokee in Georgia and the South Carolina nullification crisis as interrelated and used both sides of the nullification discourse to call out the state of Massachusetts on the contradictions of its federally leaning politics in order to gain greater political autonomy for Mashpee.

4 Scholars such as Maureen Konkle, David J. Carlson, and Andy Doolen have thoughtfully discussed the political valences of Indian Nullification and the political autonomy sought by the Mashpee community through their legal struggles. This essay builds off their work but argues that the discourse of slavery is fundamental to the discourse of nullification, and that Apess and the writers of Indian Nullification used that white supremacist valence to enact a trenchant critique of Massachusetts politics, dismantling its sentimental discourse of benevolent paternalism and laying bare the racism at the heart of the state's Indian policies. By rhetorically adopting the slaveryinfused language of "nullification" in agitating for their rights, Apess and the Mashpee exploded the dominant political discourses of Massachusetts and the antebellum United States. This essay will survey the contemporaneous discussions of Cherokee removal policy and the nullification crisis to see how Apess and the collaborative authors of Indian Nullification wrote in the presence of those political battles and deployed them within the text.

\section{Constitutional Law, Nullification, and the Cherokee Nation}

5 The Cherokee Indian nation lived across a broad swath of land covering portions of Tennessee, Alabama, and South Carolina, but the majority lived on lands within the state of Georgia. The Cherokee boundaries were made official in the eyes of the United States government in its first national treaty with the Cherokees, the 1785 Treaty of Hopewell, article 4; those boundaries were confirmed in the 1791 Treaty of Holston as well. But these treaties would prove meaningless when the state of Georgia began encroaching on the Cherokee's gold-rich lands and in 1829 and the state passed several laws asserting the state's control of Indians and their lands. These encroachments on the Cherokees provoked two significant court battles, Cherokee Nation v. Georgia (1831) and Worcester v. Georgia (1832), which set the parameters for the national discussion on Indian sovereignty in ways that came to bear on the work Apess and the Mashpee did in their conflict.

6 The legal wrangling between the Cherokees and the U.S. government reveals several issues related to the battle the Mashpee fought several years later. The Cherokee and the Mashpee were interpolated into the discourse of the "vanishing Indian" as well as the discourse of sentimental benevolence, both of which we will see in Justice John Marshall's majority ruling in Cherokee Nation v. Georgia. But that ruling, along with Justice Smith Thompson's dissent, reveals an important gap between the Cherokee, 
understood as a significant tribal community (if not a "nation") and the concept of "remnant" Indians, those small, dispersed, and diffuse Indian communities that were not to be understood as sharing in any form of national legitimacy. Even Thompson's dissent in favor of the Cherokees left little space for Mashpee and similar communities.

7 As Konkle states about Marshall's ruling in Cherokee Nation v. State of Georgia, "The problem for John Marshall's Supreme Court was that it had to assert colonial authority [over the Cherokees]-tyrannical, imperial authority, of the kind the United States had thrown off in the Revolution-while appearing not to" (17). Marshall had to validate U.S. treaty making, while finding a way to deny the Cherokees standing.

8 He managed this with his dramatic and now famous revision of the nation's relationship to the Indian nations occupying U.S. land. In his majority opinion Marshall argued that the Supreme Court could not bring the claim before Congress because they were not a foreign nation but rather a "domestic dependent nation." Marshall held this to be true for the Cherokees and for any and all Indian nations occupying land claimed by the U.S.

9 But Marshall also indulged in the rhetoric of the "Vanishing Indian" to buttress the logic of his case. It is worth quoting one telling example at length:

If courts were permitted to indulge their sympathies, a case better calculated to excite them can scarcely be imagined. A people once numerous, powerful, and truly independent, found by our ancestors in the quiet and uncontrolled possession of an ample domain, gradually sinking beneath our superior policy, our arts and our arms, have yielded their lands by successive treaties, each of which contains a solemn guarantee of the residue, until they retain no more of their formerly extensive territory than is deemed necessary to their comfortable subsistence. To preserve this remnant, the present application is made. (Cherokee Nation v. Georgia, 30 U.S. 1)

Here Marshall deployed sentimental rhetoric to color the plight of Indian nations in terms of their "remnant" status. In Marshall's telling, the contemporary Indian nation was a pale shadow of its once great past, brought low by "our arts and our arms," both Euro-American cultural superiority and Euro-American violence. The case of the Cherokee before the Supreme Court was to "preserve this remnant," where the Cherokees stand synecdochally for all the vanishing Indians across the continent. ${ }^{\mathrm{ii}}$

11 But Cherokee lives in the early nineteenth century told a different story. Marshall's rhetoric is a perfect example of Brian Dippie's claim that "The belief in the Vanishing Indian was the ultimate cause of the Indian's vanishing" (7). The Cherokees had made significant attempts to unite formally as a nation in a way that Americans would find intelligible-through print culture, farming, and democratic political organization in particular. But such "improvements" did not convince Marshall that the Cherokees were any more than a "remnant people."

Justice Smith Thompson, in his dissent, argued that whatever the "quality" of the Cherokee nation, the U.S. had always treated them as a nation and in no way had the Cherokee ceded that right. However, he too invoked the specter of "remnant people" to clarify his dissent. After claiming that the Cherokee were "sovereign and independent... not within the jurisdiction nor under the government of the states within which they were located," he makes a telling caveat:

This remark is to be understood, of course, as referring only to such as live together as a distinct community, under their own laws, usages, and customs; and not to the mere remnant of tribes which are to be found in many parts of our country, who 
have become mixed with the general population of the country; their national character extinguished; and their usages and customs in a great measure abandoned; self-government surrendered; and who have voluntarily, or by force of circumstances which surround them, gradually become subject to the laws of the states within which they are situated. (Cherokee Nation v. Georgia, 30 U.S. 1)

Even in Thompson's sympathetic stance towards the Cherokees he made sure to exclude those Indian peoples who did not, for various reasons, share in the benefits of a nation, with a "national character." This dismissal would no doubt include the Mashpee. iii But Indian Nullification displays an awareness that their "remnant" status makes their political ground more tenuous. As we will see, Apess and the Mashpee did not turn to the same arguments that the Cherokee made about their national character while still engaging with the rhetoric found in the ruling.

Konkle writes, "While autonomy conceded in treaties did not necessarily make life easier for Native peoples, it provided a mechanism for resistance to EuroAmerican authority and an opening for critique on the part of Native intellectuals and political leaders in the nineteenth century" (5). As we see with the Cherokee, that "mechanism for resistance" merely bought them time before the Supreme Court and the Jackson presidency overcame them. But treaty discourses as a mode of resistance required Indians to be organized into communities that Americans saw as legitimate, a status the Cherokee could not ultimately assume, let alone the people of Mashpee. This impasse meant that Apess and the Mashpee had to look elsewhere for a meaningful political discourse that might provide a site of resistance, and they found it in an unlikely place; in the radical separatism of the slave-owning "nullifiers" of South Carolina.

\section{South Carolina and the Crisis of Nullification}

The issue of Georgia's authority over Cherokee lands was interrelated with the infamous sectional crisis of South Carolina and "nullification," an interrelationship Apess rhetorically exploited in Indian Nullification. Georgia was ultimately reined in from intervening with the Cherokees outside of federal authority in the case Worcester v. Georgia (1832). With Andrew Jackson in office, Georgia governor Wilson Lumpkin felt confident that removal would ultimately win the day and that the federal government would not enforce Marshall's ruling. But by ignoring the ruling, Lumpkin feared he would implicitly align himself with the nullifiers of South Carolina and attract the anger of Jackson. The contemporary understanding of the Cherokee crisis and South Carolina's nullification as being woven together is important for our understanding of how Apess uses the concept of "nullification" in his text. ${ }^{\text {iv }}$ Apess held the state of Massachusetts against these two related political stances, making the state see itself in the light of Georgia's removal policy and South Carolina's slave-holding political elite.

Nullification emerged over South Carolina's resistance to a federal "protective tariff." The Tariff of 1828 was meant to protect U.S. manufacturing, but South Carolina and other Southern states believed the tariff benefitted the Northern manufacturing states at the expense of the agrarian South. Many Southern states petitioned the government to repeal or reduce the tariff, but South Carolina took the additional step of "nullifying" the tariff, arguing their constitutional right to do so. This doctrine of nullification was formulated by senator John C. Calhoun in the 1832 text The South Carolina Exposition and Protest. As described by historian Richard Ellis, Calhoun argued that "the Constitution 
was a compact among the states that had delegated only specifically defined powers to the national government and that the states had completely retained their own sovereignty" (8). If states felt the government went beyond those defined powers, "a state had the power to declare such an action unconstitutional and therefore null and void within its boundaries." This left the federal government with two options: to "refrain from enforcing the objectionable law" or attempt the nearly impossible by amending the Constitution (Ellis 8).

The Exposition created a firestorm, with much of the South eager to distance itself from South Carolina's radical position. Even those who adhered deeply to the concept of "states' rights" (including Andrew Jackson himself) saw the theory of nullification as outside of the mainstream of states' rights logic and a threat to the stability of the Union. Georgia governor Lumpkin recognized the gauntlet thrown down by South Carolina and the threat of military intervention that the conflict might produce on the part of the federal government (Ellis 112-113).

But the doctrine of nullification was about more than tariff reform or the immediate political issues of Cherokee rights. South Carolina's nullification stance produced the most sustained sectional crisis in the U.S. before the Civil War, calling into question the compact between the states and the federal government and the very concept of "union." In this regard, though the federal government won the battle, it ultimately lost the war. South Carolina managed to get the tariff reduced (though not rescinded) and never had to answer for a stance on the relationship of the states to the federal government that had no serious Constitutional founding nor overall popular support (Ellis 180).

The intersecting issues of the Cherokee and nullification taught two lessons that would come into play for the Mashpee community. The first was from the Cherokee, who attempted to conform closer to the standards of the surrounding white world while relying on the power of the federal government for legal protection, both to no avail. The second was the lesson of South Carolina, namely that radical threats against the power of the federal government, having ultimately proved successful, would go unpunished and lead to compromise.

Andy Doolen has written on the way the discourse of abolitionism informed the work of Apess, specifically arguing for the work of William Lloyd Garrison as a rhetorical and intellectual model. ${ }^{v}$ I agree that Garrison's work can be seen as a touchstone for Apess, but the Cherokee crisis and nullification provided an additional avenue through which the issue of slavery informed the political work of Indian Nullification. ${ }^{\text {vi }}$ The threat of secession and the state of Georgia's response to the federal judiciary showed that the discourse of states' rights worked as a mechanism of white supremacy and operated against both Indians and slaves alike. The state of Massachusetts publicly stood against slavery and Georgia's position towards the Cherokees and Apess used those positions to his rhetorical advantage. As we will see, Apess wedded the Cherokee crisis to Mashpee, casting Massachusetts in the role of Georgia. But instead of calling on the federal government as the Cherokees did, Apess and Mashpee called their acts of political resistance "nullification." Doing so rejected Massachusetts's understanding of itself in relation to its Indian population. Massachusetts was not dealing with an Indian community under control but a political body in a state of rebellion. 


\section{Indian Nullification and the Specter of Disunion}

21 A brief review of Mashpee's status vis-à-vis Massachusetts will help in understanding the grievances outlined in Indian Nullification. The community was set up as a kind of proto-reservation in the seventeenth century as a "plantation" for various displaced Indians of the region. As James Clifford notes, "Mashpee was originally an artificial community, never a tribe" (295), a reality that will lead to legal difficulties for Mashpee deep into the twentieth century. The colonial government of Massachusetts granted the community a relative degree of autonomy that would be slowly dismantled over the coming decades. Like other Indian lands within Massachusetts, Mashpee was located within the boundaries of a local community, but not subject to the latter's jurisdiction. They were instead beholden to state laws but had no political voice in shaping those regulations, which were handled through an overseer system (Nielsen 401). As Deborah A. Rosen writes, "according to the 1763 statute incorporating the town of Mashpee, only two of the five overseers had to be English, and all five were chosen by Indians. As it turned out, even that limited degree of self-government was short lived"; by 1778 all of the overseers had to be white (10). Donald Nielsen writes, Massachusetts "denied the individual Indian the opportunity to learn how to conduct his own affairs," by regulating how Indians handled the disposal of their land and resources (Nielsen 401). But as we will see, the state failed to protect the land it regulated on behalf of the Mashpee, and the community had no legal autonomy to protect that land on its own terms. vii

At the time of the conflict related in the book, the Mashpee were under an additional set of regulations related to their religious lives. The community struggled with the Rev. Phineas Fish, a man appointed through a 1711 bequest from Englishman William Williams for the purposes of Christianizing the Wampanoag. The community was frustrated by Fish's seeming indifference to both their spiritual and material well-being and sought to regain control of the meeting house left to his control by the Harvard trustees who oversaw the Williams bequest. It is important to note that, like the Williams bequest, the overseer system put in place by the colonial government reflected the logic of New England eighteenth-century missionary ambitions. What both the spiritual and legal regulations had in common was a discourse and practice of benevolent paternalism, one cloaked in the language of the state and the other in conversion; a discourse reflected also in Marshall's Cherokee Nation ruling. This was ultimately then a two-fold battle: A fight for autonomy from the Massachusetts legislature and a fight against the appointment of Fish.

The "rebellion" (and I put it purposefully in scare quotes) that set things in motion at Mashpee was a result of the failure of the existing system to protect the interests and resources of the Mashpee community. Apess and other Mashpee residents forced from their land a group of whites who were taking Mashpee lumber, an act that led to an altercation soon involving state authorities. The Mashpee rightfully did not see this as a "rebellion" but protection of their resources. But Apess was briefly imprisoned for his role in the confrontation and it precipitated the community's direct engagement with the state of Massachusetts for redress. The long process of engagement with the Massachusetts legislature, Harvard University, and the nearby communities of Cape Cod produced Indian Nullification of the Unconstitutional Laws of Massachusetts Relative to the Mashpee Tribe; or, The Pretended Riot Explained, published in 1835. This fascinating, 
polyvocal text is both a reflection on the Christian Indian community and a model of its politics in action. Though Apess is a strong presence throughout the text, as Barry O'Connell points out, "it is the work of many hands" (165). The text is a collection of documents including petitions to the Legislature, contemporary news reports and commentary, and private letters, all woven together and analyzed by a narration that is strongly but not exclusively that of Apess. It is that many-handed quality of the text that is significant politically and rhetorically to this essay. What Apess and the rest of the Mashpee community do in Indian Nullification is create a text that mirrors the collectivist politics of the community in opposition to Massachusetts's silencing political efforts. No one voice speaks on behalf of the Mashpee, no one person claims a heroic role in the conflict, no one individual claims ownership of the community or its political aims. Apess et al. put together a document that reflects a community of readers and writers and attempt to bring the community's lived practice into a writing practice. Indian Nullification reflects a lived political practice at odds with the benevolent paternalism imposed by the Williams bequest, the authority of the Harvard trustees, and the policies of the state of Massachusetts.

The book begins with prefatory material specifically appealing to the citizens of Massachusetts, calling them "the descendants of the pale men who came across the big waters to seek among them a refuge from tyranny and persecution" (O'Connell 167). This call to the people of Massachusetts based on their colonial history will come into play throughout the text. The book then narrates the arrival of Apess and outlines the Mashpee's grievances towards both the State of Massachusetts and Harvard University. It shares the joint resolutions made public by the tribe and then moves on to share articles from local newspapers related to the tribe's cause. In this way the book moves in its early pages through multiple voices and styles of writing, setting the tone for the whole work. Though Apess seems to shape much of the narrative as writer/editor, the community's voice emerges through those embedded texts, such as a letter sent to the Barnstable Journal about its claims, written as a collective "we" (O'Connell 165). viii

But it is the incorporation of other print sources that best reveals the polyvocality of the text. A statement titled "Marshpee Indians" (originally submitted by the tribe to the Barnstable Journal) is followed with an editorial penned by ally Benjamin F. Hallett (the tribe's attorney) for his Boston Daily Advocate, which incorporates two letters sent to Hallett by tribal spokespersons. This material from the Advocate is introduced with the following comment: "In the editorial remarks will be discerned the noble spirit of independence and love of right, which are prominent characteristics of Mr. Hallett's character" (O'Connell 196). Hallett's item in turn is followed by a more hostile editorial from the Barnstable Journal, critiquing the "revolt" of the Mashpee, which elicits the commentary of the Mashpee: "The writer here says that the Indians are vile and degraded, and admits that they can be improved. He gives no explanation of the causes of their degradation" (O'Connell 200). This series of documents and passages moves across corporately written documents by the Mashpee to newspaper editorials featuring opposing points of view. What unites these different sources is a narration that comments upon and critiques those sources. This authorial voice links these disparate sources together, and this voice is importantly not explicitly ascribed to Apess but meant to speak on behalf of the Mashpee community. It represents a kind of corporate authorship that is also a political act, a community voice in writing that speaks to Mashpee's internal coherence and its political activity. The text of Indian 
Nullification is an act of resistance; the Mashpee may be a "remnant," but they are organized and unified politically.

This collective identity animated much of the public and official writing of the Mashpee throughout the conflict. In a statement to the Harvard trustees, the Mashpee declared their unhappiness with Fish as their minister and wrote, "we do say, as the voice of one, with but few exceptions, that we as a tribe, for a long time, have had no desire to hear Mr. Fish preach" (O'Connell 175). This statement is interesting as a model of the collective practice of the Mashpee community. It declares a single tribal position on Fish, while also acknowledging that that unanimity is not completely comprehensive ("with but few exceptions"). This is an example of how the Mashpee communicate in a voice that acknowledges difference while speaking with the strength of a community united around politics and faith. That combination is necessary to the unique situation of Mashpee because it produces a discourse of resistance that speaks to both fronts of their battle, with Rev. Fish and the state of Massachusetts.

The parallels drawn between the Mashpee and the Cherokee crisis came not just from the Mashpee, but also from the larger public sphere of Massachusetts at this time. Like much of the North, the people of Massachusetts, with their federalist-leaning politics, were significantly opposed to Georgia's attempts to circumvent federal policy and displace the Cherokee from their lands. ${ }^{\text {ix }}$ In another editorial in his Boston Daily Advocate Benjamin F. Hallett writes, "We now see how unjust we have been to the Georgians in their treatment of the Cherokees, and if we persist in oppressing the Marshpee Indians, let us hasten to unresolve all the glowing resolves we made in favor of the Georgia Indians" (O'Connell 226). Hallett here played off of a sentiment already expressed in the pages of the Advocate. He again writes, "We have an overflow of sensibility in this quarter toward the Cherokees, and there is now an opportunity of showing to the world whether the people of Massachusetts can exercise more justice and less cupidity toward their own Indians than the Georgians have towards the Cherokees" (O'Connell 196). The language of "sensibility" here, like Marshall's 1831 Supreme Court ruling, is telling. Redressing the wrong of the Cherokee and the Mashpee is an act of sympathetic white benevolence as much as an issue of justice.

Despite its problems, Hallett, Apess and the Mashpee deployed that sentimental logic when effective. In a public letter circulated to multiple papers (and written collectively), the community writes:

As our brethren, the white men of Massachusetts, have recently manifested much sympathy for the red men of the Cherokee nation, who have suffered much from their white brethren; as it is contended in this State, that our red brethren, the Cherokees, should be an independent people, having the privileges of the white men; we, the red men of the Marshpee tribe, consider it a favorable time to speak. We are not free. We wish to be so, as much as the red men of Georgia. (o'Connell 205)

The Mashpee compliment the state for their "sympathy" towards the Cherokee. But they did not dwell long on this, shifting their focus to the more important issue of "freedom." "Sympathy" existed as a fleeting emotion, moved by the whims of white power; turning that sympathy towards the more concrete discourse of freedom moves beyond that sympathy.

But the discourse of freedom was also tuned to a specifically Massachusetts audience, one that cherished its historical relationship to the American Revolution. In his introduction to the book Apess writes that "he is sensible that he cannot write truly on 
this subject, without attracting the worst wishes of those who are enemies to liberty, or would reserve it exclusively to themselves" (O'Connell 168). In another collectively written letter to the Barnstable Journal, he and his collaborators describe their own situation as parallel to colonial Boston and compare the Mashpee's seizure of wood stolen by local whites to the Boston Tea Party (O'Connell 195). And most importantly for this discourse, the Mashpee community refers to its own role in the American Revolution both in this same letter and in a petition to the legislature, which reads as follows: "We also beg leave to remind your Honors that our fathers shed their blood for liberty, and we their children have had but little benefit from it" (O'Connell 250). Having sent multiple volunteers to the revolutionary effort, the Mashpee linked their community historically to the War of Independence and rightfully emphasize their own present lack of independence. This reminder is both an accurate summary of their history in Massachusetts and a successful rhetorical strategy, allowing the community the flexibility I argue is necessary for their political survival.

31 This strategy gains additional complexity when we look at the ways the community engaged the tensions around the Cherokee and nullification political conflicts. As noted earlier, the community was eager and able to align its plight with that of the Cherokee and their northern supporters against the state of Georgia. Apess and the Mashpee seemed fully aware that Georgia governor Lumpkin's refusal to defer to the Supreme Court decision handed down in Worcester v. Georgia was nullification in fact if not in name, and that Massachusetts residents were overall both sympathetic to the plight of the Cherokee and invested in the power of the federal government and the Supreme Court. But the writers of Indian Nullification did not rest comfortably with that shared political sentiment; rather, they turned it back onto white Massachusetts residents by recognizing the racial politics inherent in the discussion.

However, much of the scholarship on Indian Nullification sees the deployment of "nullification" in more narrowly political terms. Jean O'Brien writes, "Apess could only have been suggesting that Indians have the right to nullify the unjust laws of the state of Massachusetts. In effect, he is asserting a parallel between governmental entities in order to assert the political status of New England tribes vis-à-vis the state" (182). This reading attends to the more concrete goals of Apess and Mashpee but evacuates the historical and racial politics of nullification as it was argued by South Carolina's slaveholding political elite. This turns what was essentially South Carolina's attempt at dismantling the Union into a kind of reform discourse. I argue that in deploying the concept of nullification Apess and the Mashpee were forcing a radical confrontation with the politics of white Massachusetts and the New England federalist political leaning through the racial charge inherent in the term "nullification."

It is important to recognize that nullification was an unprecedented rejection of the Constitution, created and enacted by a slave-holding elite that controlled South Carolina politics. In her book The Counterrevolution of Slavery, Manisha Sinha argues "The Carolina doctrine of nullification was the political expression of a self-conscious and assertive slaveholding planter class that deviated significantly from the republican heritage of the country and the growing democratization of national politics" (10). Radically undemocratic South Carolinians pursued nullification not simply because of their unhappiness with the Tariff of 1828 , but also because they saw it as a threat to their system of racial slavery by the northern and western portions of the country. As South Carolina lawyer, politician, and pro-unionist James Petigru stated at the time, "It 
is clear that our nullifiers mean to pick a quarrel with the north about negroesNullification has done its work. It has prepared the minds of men for a separation of the States-and when the question is moved again it will be directly union or disunion" (Sinha 60).

Foregrounding the racial politics of nullification allows us to move towards a more nuanced understanding of the rhetorical work performed by Indian Nullification. Andy Doolen writes that Apess "frames his history with the nullification controversy" because

the Southern strategy was a blueprint for defending minority rights within the framework of American constitutionalism. Apess develops a doctrine of Indian nullification that at once abolishes the state's unconstitutional laws over a minority group while declaring independence from a corrupt overseer system. Like Calhoun's doctrine, Apess does not wish to threaten secession.... He is committed to a position that enables the Mashpee to remain within the United States with specific constitutional rights. (Doolen 166)

Doolen reads the constitutionalism of nullification as a political stance and therefore sees Apess's usage in more literal terms. But Apess was also doing something more politically radical by looking in two directions that are seemingly contradictory: To the plight of the Cherokees of Georgia and the federalist argument that Georgia overstepped its bounds (an argument the people of Massachusetts supported) and to the logic of the slave-holding elite of South Carolina, a radically anti-federalist position that brought South Carolina to the brink of military conflict with the U.S. government and that was understood to be a stance on both the tariff and southern slavery. But what Apess and his collaborators did was not articulate the contradiction on their own, but rather turn it back onto the state of Massachusetts and its policies towards Mashpee. The book aimed not just to reform the Massachusetts law in order to gain greater political independence for Mashpee (though Indian Nullification is indeed doing that), but also to short-circuit the logic of white, federalist, benevolent Massachusetts. Apess and the Mashpee thus dared to align themselves rhetorically with arch-slave owners like Calhoun and the elites of South Carolina.

The idea of a "remnant" Indian community speaking in the political language of a slave-holding separatist elite in and of itself ruptures the political logic of Massachusetts. The very title is a provocation on a scale that I feel critics have not fully appreciated, even when recognizing the work's obvious political valences. To bring Calhoun's states' rights provocations down another level, from federal versus state to state versus local, and to bring these provocations into the conflict between Indian communities and the states' white elected officials is an unprecedented move in the realm of Indian activism of this time. The attempt is no doubt connected to the political autonomy that Konkle and others analyze, but the rhetorical reversal it achieves damns Massachusetts and calls into question its established political order. The specter of Indian communities as politically untamable as southern nullifiers is insurrectionary. To invoke nullification is not simply to engage in the political language of the day or an ironic reversal (though it is both of those), but also to bring the potential of disunion and disorder within the borders of Massachusetts.

One example reveals this logic at work in the text. The Mashpee were told by a Massachusetts judge, through an agent to the Indians, that "merely declaring a law to be oppressive could not abrogate it; and that it would become us, as good citizens whom the government was disposed to treat well, to wait for the session of the 
Legislature and then apply for relief" (O'Connell 183).Though not by the name of "nullification," Barnstable county Justice of the Peace John Reed tells the Mashpee the same thing that Jackson and his allies told South Carolina (Gura 84). But Apess, in a parenthetical aside following this summary, plays a card unavailable to South Carolina: "surely it was either insult or wrong to call the Marshpees citizens, for such they never were, from the Declaration of Independence up to the session of the Legislature in 1834" (O'Connell 183). In this move the text reveals what is distinctly "Indian" about the Mashpee's deployment of nullification. In the South Carolinian formulation, nullification was an abrogation of a compact made among the states without constitutional logic or precedent; but the Mashpee Indians were never part of any compact, constitutional convention, or legislative body. Apess brings the provocative language of nullification into play in order to reveal a significant difference: citizenship. The Mashpee were asked to wait on a deliberative political process that they could not actually take part in-they could not send an elected representative to the Massachusetts legislature and their petitions merely placed them at the mercy of legislative benevolence. Like the Cherokee before the Supreme Court, they requested political recognition but were denied it. In this way, adopting the discourse of nullification goes beyond provocation (though provocation is an important rhetorical mode here) and becomes a way to break apart the incoherence of the Mashpee's role in the state's political life. They were apart from the political realm but asked to submit to it nonetheless; they were jailed for rioting based on state laws they could not create and defending laws that were not enforced.

Like South Carolinian nullifiers, Apess and the Mashpee invoked the legacy of the American Revolution to support their resistance. Addressing the reader they write "I will ask him how, if he values his own liberty, he would or could rest quiet under such laws. I ask the inhabitants of New England generally how their fathers bore laws, much less oppressive, when imposed upon them by a foreign government" (O'Connell 211). This statement invokes the patriotic sympathies of a Massachusetts readership and likens the Mashpee to such patriots, a move like that of the South Carolina nullifiers. But again, the specter of citizenship haunts this language if one follows its logic. If South Carolinians were rebels, then they stood outside of the union, though claiming to be staunch defenders of its constitutional principles. But the Mashpee did stand outside that union and therefore had a logical case for resistance to unjust laws.

In paralleling themselves to the Cherokees of Georgia, the Mashpee highlighted their similarities and imply that the Northern federalist logic, which defends the Cherokee, should apply to Mashpee as well. But this parallel to South Carolina reveals a politically useful gap-the role of citizenship in taking part in the political process. The Mashpee wanted something complex but legitimate, to have autonomy from the Massachusetts system and political power within it. If Apess's dance on both sides of the nullification debate seems contradictory, it is precisely because the situation was contradictory. No legitimized political discourse existed in the antebellum United States to give the Mashpee what they deserved-Marshall wrote all Indians out of nationhood, Thompson wrote all "remnants" out of political standing in his dissent, and Massachusetts "oversees" the Mashpee, denying them political representation and community independence. Nullification was then the wedge that Apess and the Mashpee used to disrupt this situation, using the national panic South Carolina initiated beginning with Calhoun's Exposition and Protest. Invoking nullification within an argument about Indian rights, Indian Nullification disrupts Massachusetts's understanding of its federalist 
politics. Like southern Democrat Andrew Jackson, Massachusetts was opposed to Southern nullification, but its treatment of the Mashpee made the state more like Jackson in his stand against the Cherokee; the state's politics were laid bare.

These contradictions might also speak to the inherent problem of "sovereignty" when discussing Mashpee as sovereignty has a complex place in the discussion of Indian political community. Rochelle Raineri Zuck writes, "Apess draws on the Israelite captivity among the Egyptians" to "elicit sympathy" from his local audience and ultimately "assert Mashpee sovereignty" (15). Other scholars, such as Deborah A. Rosen, have taken sovereignty as the aim of Apess's work in Mashpee. Taiaiake Alfred criticizes the Western, "adversarial," and "coercive" nature of the term "sovereignty" (59). On the other hand, Amanda Cobb points in a productive direction, arguing, "Our understanding of sovereignty must be flexible and negotiable but not so flexible that the term can mean anything" (116).

41 Keeping that flexibility in mind, Indian Nullification offers its own clear vision of political sovereignty-democratic community representation, community-based decision making, and recognition of their independent and protected status by the state of Massachusetts. But what the text offers is also what Scott Richard Lyons calls "rhetorical sovereignty," the "inherent right and ability of peoples to determine their own communicative needs and desires... to decide for themselves the goals, modes, styles, and languages of public discourse" (Lyons 448-49). With this in mind, we can look back on the work of Apess and the Mashpee as an act of rhetorical sovereignty that also critiques the very instability around that concept. The text stakes out the community's values and identity in the context of their political battles by highlighting the myriad conflicts over the concept of sovereignty happening at their own political moment-the sovereignty of American Indian communities, both "nations" and "remnants," the sovereignty of individual states and communities within states, etc. Indian Nullification reveals how unstable the word was in this moment; complicating the concept of sovereignty as Apess and the Mashpee did is an attempt to avoid the inevitable political endgame of sovereignty in U.S.-Indian relations: violence and removal.

\section{Conclusion}

Following the parallels between the Cherokee and the Mashpee means that both are fighting for rights inherent in the U.S. Constitution, not only the discourse of "liberty" but also the more specific rights of treaty and property rights. But by framing the Cherokee and Mashpee in a parallel political situation means that Massachusetts was not the benevolent ally of the Cherokee (as they saw themselves) but more like Georgia and other Americans interested in eradicating Indians for their land. The Mashpee write, "Other editors speak ill enough of Gen. Jackson's treatment of the southern Indians. Why do they not also speak ill of all the head men and great chiefs who have evil entreated the people of Marshpee? I think Governor Lincoln [of Massachusetts] manifested as bitter and tyrannical a spirit as old Hickory ever could, for the life of him" (O'Connell 238). Apess and the Mashpee revised the state's narrative of benevolence towards the Cherokees by reframing their Indian sympathies around policies in their own state, revealing that Massachusetts's sympathies were deeply flawed as they extended only to those Indians they had no relationship to. In doing so, 
they deployed nullification as the most loaded rhetorical weapon available, a concept that invoked slave power, the sectional fragmentation of the union, and armed conflict between state and federal power. They drew their Massachusetts readership into this issue by inverting their role in the conversation, turning them, as in the above quote, into General Jacksons.

In this regard, the writers of Indian Nullification offered a unique political discourse in the antebellum United States, one that deployed the sectional conflicts of the day but moved beyond those sectional differences. The dichotomies that shaped the era's political conversation-North/South, federalist/states' rights, slavery/abolitionismwere reworked and reframed while the role of sentimentalism in the discourse of race and benevolence was disrupted. But if Indian Nullification subverted the sectional discourse, it could not overcome that discourse. The movement of the U.S. towards the Civil War revealed the impossibility at the time of thinking beyond regional power politics and the economy of slavery.

Well into the twentieth century, Mashpee continued to do legal battle over its community rights and formations-the battles of the 1830s were part of a much longer struggle. We can then turn back to Indian Nullification for a window into another sense of political and social formation, tenuously but tenaciously made available by the Mashpee community in their writing and lives. They with Apess created a political discourse that both engaged and elided the power of the state. Their discourse asserted a communal Indian identity that was also flexible and inclusive, a discourse that by undercutting the dominant logic of its day imagined a freer life for the community.

\section{BIBLIOGRAPHY}

Bragaw, Stephen G. "Thomas Jefferson and the American Indian Nations: Native American Sovereignty and the Marshall Court." Journal of Supreme Court History 31.2 (2006): 155-180. Print. Campisi, Jack. The Mashpee Indians: Tribe on Trial. Syracuse: Syracuse University Press, 1991. Print. Carlson, David J. Sovereign Selves: American Indian Autobiography and the Law. Urbana: University of Illinois Press, 2006. Print.

Cherokee Nation v. Georgia, 30 U.S. 1. Supreme Court of the United States. 1831. Supreme Court Collection. Legal Information Institute, Cornell University Law School, n.d. Web. 3 March 2018.

Clifford, James. The Predicament of Culture: Twentieth-Century Ethnography, Literature, and Art. Cambridge: Harvard University Press, 1988. Print.

Cobb, Amanda J. “Understanding Tribal Sovereignty: Definitions, Conceptualizations, and Interpretations." American Studies 46.3/4 (2005): 115-132. Print.

Dippie, Brian W. The Vanishing American: White Attitudes and U.S. Indian Policy. Middletown: Wesleyan University Press, 1982. Print.

Donaldson, Laura. "Making a Joyful Noise: William Apess and the Search for Postcolonial Method(ism)," Interventions: International Journal of Postcolonial Studies 7.5 (2005): 180-198. Print. 
Doolen, Andy. Fugitive Empire: Locating Early American Imperialism. Minneapolis: University of Minnesota Press, 2005. Print.

Ellis, Richard E. The Union at Risk: Jacksonian Democracy, States Rights and the Nullification Crisis. Oxford: Oxford University Press, 1989. Print.

Formisano, Ronald P. The Transformation of Political Culture: Massachusetts Parties, 1790s-1840s. New York: Oxford University Press, 1983. Print.

Gura, Philip F. The Life of William Apess, Pequot. Chapel Hill: University of North Carolina Press, 2015. Print.

Haynes, Carolyn. “'A Mark for Them All to... Hiss At': The Formation of Methodist and Pequot Identity in the Conversion Narrative of William Apess." Early American Literature 31.1 (1996): 2544. Print.

Howe, Daniel Walker. What Hath God Wrought: The Transformation of America, 1815-1848. Oxford: Oxford University Press, 2007. Print.

Konkle, Maureen. Writing Indian Nations: Native Intellectuals and the Politics of Historiography, 1827-1863. Chapel Hill: University of North Carolina Press, 2004. Print.

Lyons, Scott. "Rhetorical Sovereignty: What Do American Indians Want from Writing?" College Composition and Communication 51.3 (2000): 447-468. Print.

Nielsen, Donald M. “The Mashpee Indian Revolt of 1833.” The New England Quarterly 58.3 (1985): 400-420. Print.

O’Brien, Jean M. Firsting and Lasting: Writing Indians Out of Existence in New England. Minneapolis: University of Minnesota Press, 2010. Print.

O'Connell, Barry, ed. On Our Own Ground: The Complete Writings of William Apess, a Pequot. Amherst: University of Massachusetts Press, 1992. Print.

Rifkin, Mark. "Shadows of Mashantucket: William Apess and the Representation of Pequot Space." American Literature 84.4 (2012): 691-714. Print.

Rosen, Deborah A. American Indians and State Law: Sovereignty, Race, and Citizenship, 1790-1880. Lincoln: University of Nebraska Press, 2007. Print.

Sinha, Manisha. The Counterrevolution of Slavery: Politics and Ideology in Antebellum South Carolina. Chapel Hill: University of North Carolina Press, 2000. Print.

Taiaiake, Alfred. Peace, Power, Righteousness: An Indigenous Manifesto. Oxford: Oxford University Press, 1999. Print.

Zuck, Rochelle Raineri. “William Apess, the 'Lost Tribes,' and Indigenous Survivance.” Studies in American Indian Literatures 25.1 (2013): 1-26. Print.

\section{NOTES}

i. See Konkle 15, Carlson 116-117, and Doolen, chapter 5. I will return to these issues later in the article.

ii. This is what Konkle calls "the strong arm of sympathy for Indians in the nineteenth century" (121).

iii. The New Bedford Press (Massachusetts) used such language in an article on the Mashpee: "The remnants of that race of men who once owned and inhabited the forests and prairies of the old 
Colony that have now given place to large and populous villages and the busy hum of civilized man, are, it would seem, somewhat dissatisfied with the manner in which they are governed by the State authority" (O'Connell 191).

iv. As Justice Story wrote to Justice Marshall "The recent attacks in Georgia and the recent Nullification doctrine in South Carolina are but parts of the same general scheme, the object of which is to elevate an exclusive State sovereignty upon the ruins of the General Government” (quoted in Bragaw 158).

v. Doolen writes, "By exposing the ideological nature of white power and by nationalizing the effects of slavery, Garrison provided a means for connecting the plight of New England Indians to the histories of slavery" (158).

vi. Mashpee residents also had a long history of welcoming black and other Indian residents into the community through marriage and adoption, which explains the community's understanding of how black and Indian forms of unfreedom were related. See Clifford, 307.

vii. The situation of Mashpee possesses striking parallels to the Pequot reservation of Mashantucket in Connecticut, a community where several of Apess's relatives resided. Mark Rifkin writes about Mashantucket in relation to Apess's work, calling that community a "shadow referent" in A Son of the Forest. Think about the connections between these two communities helps us understand how the issues Apess addresses in Indian Nullification were perhaps formed through his specific history with another embattled New England Indian community. See Mark Rifkin, "Shadows of Mashantucket: William Apess and the Representation of Pequot Space." American Literature 84:4 (Dec 2012): 691-714.

viii. O'Connell suggests that William G. Snelling probably edited the collection and wrote its introduction (168).

ix. I use the term "federalist" here not to refer to the specific Federalist Party, which no longer existed at this time, but to the nationalist political values popular in Massachusetts during this period. Party labels shifted at this time, but the values of the Federalist and later Whig parties maintained dominance in Massachusetts politics. See Formisano, Ronald P. The Transformation of Political Culture: Massachusetts Parties, 1790s-1840s. New York: Oxford University Press, 1983.

\section{ABSTRACTS}

This article situates the work of American Indian writer and activist William Apess in the context of contemporaneous debates around removal of the Cherokee nation from the state of Georgia and the secession crisis brought on by South Carolina. These two national political battles inform the work Apess does with the Mashpee Indian community of Cape Cod, represented by their collected work The Indian Nullification of the Unconstitutional Laws of Massachusetts, Relative to the Marshpee Tribe: or, The Pretended Riot Explained (1835). Building on the scholarship by Maureen Konkle, Andy Doolen, and others, this article argues that Apess frames the state-level political battle of the Mashpee in the larger national context of removal and southern secession as a means of disrupting the political logic of the state of Massachusetts. In seeing the political treatment of the Cherokee by the federal government, Apess rhetorically recasts the Mashpee community as "nullifying" state law as a means to both barter for enhanced rights for the community and, more importantly, call into question what Indian citizenship and sovereignty meant for the most vulnerable forms of Indian community in antebellum New England. 
INDEX

Keywords: William Apess, nullification, Native American literature, United States history, law and literature

\section{AUTHOR}

\section{NEIL MEYER}

Neil Meyer is Associate Professor of English at LaGuardia Community College, City University of New York (CUNY). He works in the fields of early American Studies and composition studies. His work can be found in New England Quarterly and Early American Studies. 